\title{
Olga Turysheva
}

\section{WITH THE TRUTH OR WITH CHRIST? LARS VON TRIER'S DIALOGUE WITH FYODOR DOSTOYEVSKY}

The article considers the central film cycles of the contemporary Danish director and scriptwriter Lars von Trier (Golden Heart Trilogy, USA, Depression Trilogy). The author argues that the Danish artist's creative work is to a significant extent influenced by F. M. Dostoyevsky's works. While his early Golden Heart Trilogy is rooted in the philosophical ideas of the Russian writer when depicting a Christ-like man, starting with the USA trilogy, von Trier denies the principles Dostoyevsky developed based on his faith in Christ. The author of the article examines the processes underlying the development of this worldview in the Danish director's creative work and puts forward a hypothesis that in his latest works, von Trier recreates the type of consciousness that concerned the Russian writer and was primarily reflected in the image of Ivan Karamazov.

Keywords: Lars von Trier; F. M. Dostoyevsky; Christ-like character; gospel motifs; polemics with Christianity; literature and cinema.

Статья посвящена центральным кинематографическим циклам современного датского режиссера и сценариста Ларса фон Триера («Golden Heart Trilogy», «USA», «Depression Trilogy»). Обосновывается тезис об особом характере ориентированности датского художника на творчество Ф. М. Достоевского. Если ранняя трилогия «Золотое сердце» в изображении христоподобного человека очевидно опирается на философские решения русского писателя, то начиная с трилогии «USA» фон Триер явно отвергает те смыслы, которые Достоевским были выстроены в опоре на веру в Христа. Рассматривая процесс становления данной мировоззренческой позиции в творчестве датского режиссера, автор статьи выдвигает гипотезу о том, что в своих последних произведениях фон Триер воспроизводит тот тип сознания, который был предметом размышлений русского писателя и получил свое первостепенное художественное воплощение в образе Ивана Карамазова.

Ключевые слова: Ларс фон Триер, Ф. М. Достоевский, христоподобный герой, евангельские мотивы, полемика с христианством, литература и кинематограф. 
The cinematography of Lars von Trier, a contemporary Danish director and screenwriter, evokes persistent associations with the works of Fyodor Dostoevsky. The basis of such an admission are the themes, motifs and images of Trier's cinematographic work, which clearly alludes to Dostoevsky (at least for the viewer who is well acquainted with Russian literature). They indeed appear so frequently in the films of the Danish director that the allusions appear deliberate. At the same time, this phenomenon has not as yet become a subject of scholarly consideration, in spite of the fact that interest in the work of Trier has spurred several monographs [Бьоркман; Долин, 2015; Торсен; Badley; Lumholdt; Tiefenbach].

In this article I argue that von Trier's films are reminiscent of Dostoevsky not only because they contain direct and probable references to his works, but also for other reasons. In fact, they reflect a particular worldview, which has been a long-term subject of reflection about the Russian writer, as embodied in his central characters and his own statements. Primarily, consider the letter to N. D. Fonvizina dated 1854 in which Dostoevsky admitted the possibility of attaining truth outside of the idea of Christianity, but then bluntly rejected it for himself.

Я скажу Вам про себя, что я - дитя века, дитя неверия и сомнения до сих пор и даже (я знаю это) до гробовой крышки. Каких страшных мучений стоила и стоит мне теперь эта жажда верить, которая тем сильнее в душе моей, чем более во мне доводов противных. И, однако же, Бог посылает мне иногда минуты, в которые я совершенно спокоен; в эти минуты я люблю и нахожу, что другими любим, и в такие-то минуты я сложил в себе символ веры, в котором все для меня ясно и свято. Этот символ очень прост, вот он: верить, что нет ничего прекраснее, глубже, симпатичнее, разумнее мужественнее и совершеннее Христа, и не только нет, но с ревнивою любовью говорю себе, что и не может быть. Мало того, если 6 кто мне доказал, что Христос вне истины, и действительно было бы, что истина вне Христа, то мне лучше хотелось бы оставаться со Христом, нежели с истиной ${ }^{1}$ [Достоевский, с. 176].

This epistolary quote has different critical readings. I follow the interpretation of L. I. Saraskina for whom the "creed" that Dostoevsky writes about is the "result of the fact that he realized... that Christ was the best, the ideal, and this was the truth in itself. That same truth that becomes only clearer in woe." And further:

${ }^{1}$ I want to say to you, about myself, that I am a child of this age, a child of unfaith and scepticism, and probably (indeed I know it) shall remain so to the end of my life. How dreadfully has it tormented me (and torments me even now) this longing for faith, which is all the stronger for the proofs I have against it. And yet God gives me sometimes moments of perfect peace; in such moments I love and believe that I am loved; in such moments I have formulated my creed, wherein all is clear and holy to me. This creed is extremely simple; here it is: I believe that there is nothing lovelier, deeper, more sympathetic, more rational, more manly, and more perfect than the Saviour; I say to myself with jealous love that not only is there no one else like Him, but that there could be no one. I would even say more: If anyone could prove to me that Christ is outside the truth, and if the truth really did exclude Christ, I should prefer to stay with Christ and not with truth. 
The tormented soul, struck by a long-lasting woe, craves faith and finds it; for in faith (but not in doubt or unbelief) the truth is contained. <...> He had witnessed on his own how beautiful, deep, sympathetic, intelligent, courageous, and indeed perfect Christian love can be. Here all the words are in their place, and everything is filled with real meaning and verified by personal practice. He could even say that this love is brave, selfless, and compassionate, that it does not seek what is in its interest. There is nothing better than this love and this truth and there cannot be. He, the child of unbelief and doubt, up until now and up until his own end, knows it firsthand, because he has experienced minutes of ultimate tranquility when tormenting neglect leaves him, when he loves himself and is loved by the others. Christ and no one else; this is what the Creed of Faith of 1854 means. Christ is forever; Christ means those same minutes of tranquility, love, clarity and sanctity that God sometimes sends him. Christ has found his way into the heart of Fyodor Dostoevsky, a man of an epoch that is filled with unbelief and doubt, and Dostoevsky will remain in this doubt for the rest of his life. With Christ, till the end, till his death hour. With Christ, with Him, and not against Him whatever it takes and be as it may [Сараскина, с. 343-344].

In the process of reconstructing the worldview envisioned in Lars von Trier's cinematography, one has to acknowledge the opposing direction of his philosophy. In his last works, von Trier reproduces that tragic type of consciousness which, tormented by scepticism and disappointment, remains with the Truth and not with Christ. Here the Truth is not being identified with the idea of Christian love; on the contrary, it is opposed to it due to the unreliability and impossibility of implementing the Christian ideal. This opposition is observed in the works of the Danish director particularly in his contemplation of Dostoevsky's heroes.

This position is expressed with exceptional bleakness in his last Depression Trilogy, which includes Antichrist (2009), Melancholia (2011) and Nymphomaniac (2013). Von Trier's work on the films in this cycle is accompanied by an obvious crisis in his worldview. In a number of interviews, von Trier declares his schism with Catholicism and embraces atheism, disappointed in the faith in a merciful God. Mercy, both divine and human, is conceptualized in these films as a grand illusion, a nonviable idea that has nothing in common either with the truth of life or with reality itself. "It is necessary to listen to nature, to probe at it", von Trier said in one of the interviews, "then it becomes obvious that everywhere suffering and pain reign alone. All are struggling to survive but they die: here's the idyll. I find it hard to accept the idea that this nature was created by a just God" [Долин, 2009].

The evolution of this perception can be effectively traced to the main cinematographic cycles of von Trier. The early Golden Heart Trilogy, consisting of Breaking the Waves (1996), Idioterne (Idiots) (1998) and Dancer in the Dark (2000), is obviously devoted to the miracle of Christian love. It is within this paradigm that all the films in this cycle make use of 
hagiographical poetics. All of them contain a tale of the sacrifice of the Christ-like human, who consents to prosecution and death not only in the name of salvation of the other but also in the name of redemption for his own guilt before the other.

Bess, the protagonist of Breaking the Waves, rises to ultimate heights of self-sacrifice, humbly accepting all the trials in an attempt to save her husband from death. She supports his idea of sickness, withstands the loss of her good name, the contempt of the crowd, the disgust of her own mother, the actual expulsion from the house and, finally, the fear of painful death. The attitude of Bess' gest is emphasized in the film by repeated comparisons with Christ. Moreover, the story of Bess ends by complying with the final canon of the hagiographic genre: a Miracle in the Tomb.

Karen, the Idiots' protagonist, in a conscious "god's fool's" act, provokes her own expulsion from home. On the one hand, this provocation expresses her need for punishment for the guilt towards her family; on the other hand, it celebrates her willingness to sacrifice herself for the salvation of the commune. The paradox lies in the fact that Karen does not share the ideals of the founders of the commune; in fact, she often directly disagrees with them. In her sacrifice, she is driven solely by compassion, and in her story this compassion appears stronger than the need to return to her family, redeeming her cowardice with repentance.

The heroine of the Dancer in the Dark sacrifices her own life to save her son. Her sacrifice, firstly, involves involuntary murder: Selma kills her ex-friend who betrayed her, stealing the savings intended for her son's operation; however, she kills at the man's own request, shouldering the burden, with which he was unable to cope. And secondly, her sacrifice is manifested in the rejection of the possibility of salvation; not wanting to hurt her son, she conceals the true reason for her crime and agrees to an absurd accusation and receives the death penalty.

The next cycle, an unfinished USA trilogy, also portrays the Christ-like human, but in a quite different situation, the one that discloses sacrifice as a form of "falsely acquired virtue", citing the opening of Ivan Karamazov's confession to Alyosha. Grace, the protagonist of the two films in this cycle, Dogville (2003) and Manderlay (2005), professes the idea of zealous love, but fails to withstand the horrors that follow her aspirations for compassion, forgiveness, and understanding. In both films mercy turns into violence and humiliation on the part of those to whom she selflessly served in accord with the Christian Commandment of love. To that end, in the finale of both films, Grace denounces her merciful intentions and turns into an executioner. In Dogville she agrees to destroy the entire city, including an infant, and personally takes part in the execution of the person whom she considers to be the main traitor; in Manderlay she flogs a former slave who challenged her righteous conviction in the moral uprightness of her mission. Simultaneously, Grace experiences the deepest disappointment both in human nature, and in her own sacrifice. 
The means by which the heroines of the Golden Heart Trilogy succeeded, this cycle's heroine cannot withstand; she is not capable of sustaining her position till the end. However, her final revolt does not receive the author's condemnation. While the endings of the heroines' stories in both films are undoubtedly presented as failures, von Trier seemingly acquits the cruel upheaval, concentrating the viewer's attention on the

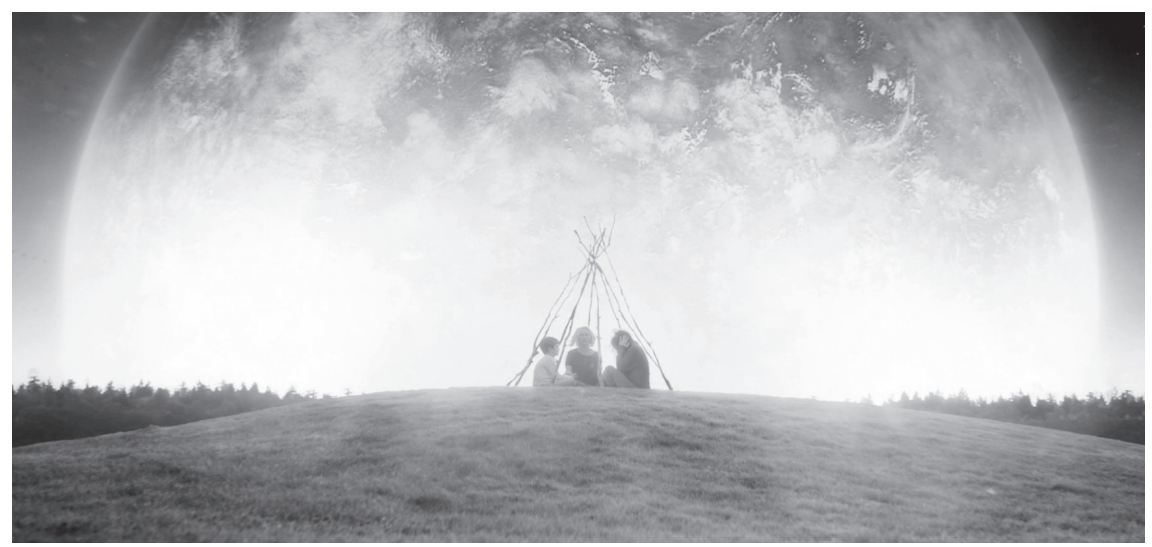

Characters see the coming of the Apocalypse in the golden cave

impossibility of imitating Christ. The sacrifice is deemed impossible not as much because the protagonist is insufficiently strong or persistent, but rather because her selfless efforts appear only to worsen the evil and to confirm human vice. In this cycle, mercy in a paradoxical but convincing way turns into the source of guilt.

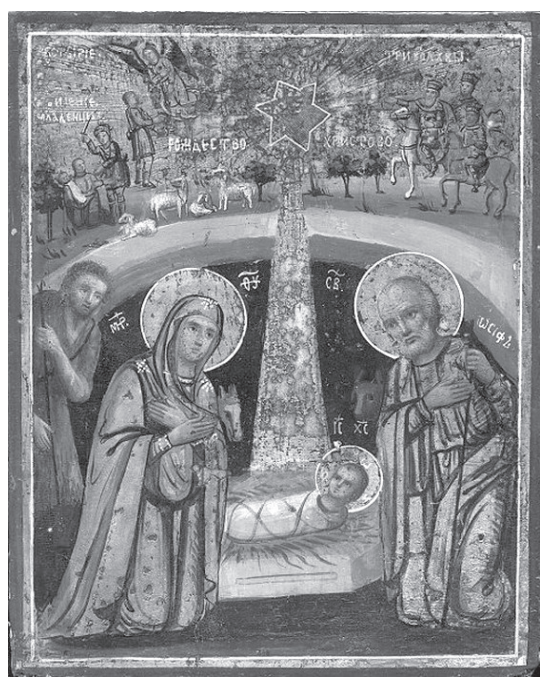

Orthodox Christian icon of Nativity ( $19^{\text {th }}$ century)

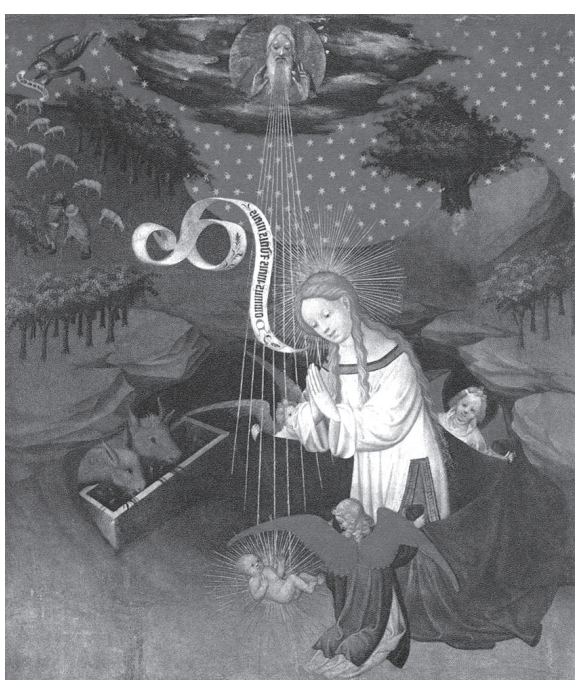

Meister Francke. Nativity (1424) 
Finally, in the Depression Trilogy the story is not about the individual disappointment of the Christ-like human with the possibility of mercy, but is rather about the total failure of the postulates upon which Christian culture is based.

In "Antichrist", von Trier exposes the Christian cult of repentance, showing the monstrous results of feelings of intense guilt. In Melancholia the Christian belief in immortality and salvation comes under the artist's critique. This is a film about the end of the world, and it asserts the finality of death: succinctly articulated in its thesis, "No one shall be saved". In Nymphomaniac, the final film of the trilogy rejects the possibility of genuine compassion and selfless aid. In these films, the central Christian tenets - the redeeming ability of the repentance, the faith in immortality and salvation, and the hope at understanding and compassion - are pictured as unfounded illusions, reliance upon which entails the most terrible consequences. As Anton Dolin, a critic of von Trier's work, rightly notes in his review of Nymphomaniac: von Trier is out on a "crusade against humanism, consisting of half a pragmatic hypocrisy, half a voluntary self-deception" [Долин, 2014]. It seems that von Trier's crusade is even broader: it is against the Christian doctrine itself and rejects not only the possibility of an attitude of humanism, but also the possibility of God's love for man.

A telling example of this observation is reflected in the final scene of Melancholia. In the backdrop of the coming Apocalypse, Justine, the main protagonist who declared the impossibility of salvation, seemingly plays out the ritual of the birth of God: together with her beloved nephew she builds a shelter, which she calls "the golden cave" or "the magical grotto".

The symbolism of this image is very clear: she refers to the cave of the Nativity. In fact, the two go on constructing a hut of thin branches, which are barely attached together. The design of their "asylum" obviously reproduces a blueprint that was very popular in the iconography of Jesus lying in the manger; the crib was often depicted inside the cone formed by the rays of the star of Bethlehem. It is inside this very cone that the heroes meet the Apocalypse. In the finale, they are an iconically constructed cadre, symbolically lit by the light of the Nativity Star. However, the symbolic presence of baby Jesus in the scene of the Earth's end does not appear to carry a meaning that glorifies life. In Lars von Trier's version, this image is not connected to the mythological idea of eternal resurrection, but rather with the idea of the absolute end that cannot be avoided with any sacrifice. The heroine, who tries to console her nephew with the illusion of salvation in the "golden cave", in fact implies nothing but the ineluctable death of God. In an act of protest against the illusion of salvation and immortality, she symbolically mortifies God in his infancy: in her point of view, the Son of God will inevitably share the destiny of all earthly creatures; similarly her beloved nephew will not reach the age of salvation and will not fulfill his sacrifice. 
Exposing Christianity as a system of illusionary ideas, von Trier openly alludes to Nietzsche's pathos of denunciation. The name of the first film from the Depression Trilogy duplicates Nietzsche's book Der Antichrist, which has the subtitle, "Fluch auf das Christenthum" ("Curse on Christianity"). It seems quite likely that this citation reveals the author's position, which denounces Christian utopianism. However, this position, in my opinion, is not borne out merely from blindly following Nietzsche, but from his reflections upon Dostoevsky. There are many allusions to Dostoevsky in the works of Trier, although the director himself never comments on these. While the questions of the interviewers about other artistic influences are usually answered willingly, von Trier only briefly acknowledged his acquaintance with Dostoevsky's works.

In a brief comment that von Trier offered in a conversation with A. Dolin, the director confides that, while getting ready to stage the story of purification through suffering and pain, he read The Brothers Karamazov (Долин, 2011). I think that his silence demonstrates the unique presence of Dostoevsky in the artistic consciousness of von Trier, not only as a writer, but also in his rejection of faith. This is true especially for the last two trilogies, USA and the Depression Trilogy. Trier's early Golden Heart Trilogy, on the contrary, is oriented towards the semantic meaning of the Russian philosopher's depiction of the Christ-like human. In USA, the cycle that openly addresses Dostoevsky's polemics, the storylines emphasize the weakness and vice of human nature as well as its inability to attain freedom, which clearly reference Ivan Karamazov's confession and his poem.

Finally, in Depression Trilogy, a whole complex of Dostoevsky's motifs can be observed. Thus, the nameless heroine of the Antichrist persistently evokes the figure of Lisa Khokhlakova, the heroine of The Brothers Karamazov. Von Trier seemingly extracts the tremendous potential, only implied in Dostoevsky's character, Lisa. Dostoevsky's heroine merely imagines how she will be eating pineapple compote, witnessing the slow death of the crucified boy. Trier's heroine proceeds further to fulfill her vicious fantasies. At first, she abuses her own son, causing him discomfort and pain by making him wear switched shoes; later, she is complicit in his death paradoxically through her laissez-faire attitude. It is emphasized in the film that the mother understood the danger of the situation in which her child was exposed to death; she in fact sacrificed him for her own experience of pleasure. Moreover, the Antichrist protagonist can be juxtaposed to Lisa Khokhlakova by the passionate will to self-punishment. Von Trier obviously examines the same phenomenon as Dostoevsky: the terror of experiencing one's own evil and the need to assert one's own guilt.

In Melancholia Trier portrays the heroine, whose actions cannot be described otherwise than the "return of the ticket to God", proclaimed by Ivan Karamazov. That is, she is convinced that humanity is not worthy of salvation, and she systematically calls on the Apocalypse, longing for the rogue planet to collide with Earth and celebrating the inevitability of this event as her true wedding. 
Nymphomaniac, besides developing the theme of destructive lust, reenacts the episodes from the second part of Notes from the Underground, concerning the relationship of the Underground Man and Lisa. Both protagonists in the film, Seligman and Joe, reflect the underground as a psychological state. For Seligman, the underground is culture: his life has a singularly intellectual dimension; his complete isolation from real life, which is emphasized by von Trier by alluding to his virginity. He, like the Underground Man, "can go nowhere except into reading". The proximity of Seligman to Dostoevsky's hero is manifested also in the depiction of his dwelling: in fact, he is living in a basement where no direct sunlight can penetrate. Joe, who is Seligman's antagonist, also reflects the underground in her isolation from others. Her isolation manifests through the peculiarities of her sexuality, conceptualized as guilt during her conversation with Seligman. Seligman plays the role of an ever-understanding savior for the penitent nymphomaniac, much as the Underground Man does for Lisa. Similar to Dostoevsky's hero, Seligman seeks to profit from this support, wanting to fulfil his own desire, for which he pays with his life in the film's final scene. If Dostoevsky's heroine "drags her offense along with her", von Trier's fires a bullet into her pseudo-savior.

Citing Socialism and Christianity, an article written by Dostoevsky, T. A. Kasatkina insists that the monologue of the Underground Man, according to the author's idea, is meant to demonstrate, through contradiction, the "necessity of faith and Christ" and therefore has positive potential [Касаткина]. In von Trier's film, the monologue belongs to the nymphomaniac, and the Underground Seligman is pictured as her auditor in whom she entrusts with the final verdict on her life because she sees Christ in him, or, as she puts it, "the only friend". However, his final selfdisclosure, shattering the ethical illusions of the heroine and the audience alike, does not offer a modicum of positive meaning.

Thus, in his late work (as opposed to early Golden Heart Trilogy) von Trier rejects the meanings, which were constructed by Dostoevsky in his reliance upon faith in Christ. The mercy in Trier's interpretation is not simply untenable, but it actually turns into its opposite, criminal hypostasis (USA); the admission of guilt does not save, but kills, turning the repentant heroine into a murderer and one who commits suicide (Antichrist); the desire for self-destruction and the destruction of all life gets powerful exculpatory reinforcement (Melancholia); finally, understanding the horror of the underground existence does not deliver any prospects: the process of admission of guilt by the heroine gets interrupted by the murder (Nymphomaniac).

And yet, sometimes the "necessity of faith and Christ" shines through the darkest corners of the Trier's world. For example, the Antichrist is devoted to Andrei Tarkovsky, whom Trier, as he declares in an interview with Anton Dolin, "honors as Jesus" [Долин, 2011]. Reinforcing this idea is the scene from Melancholia, depicting Justine's parting from life. Although in the course of the story she persistently proclaims that life on Earth is evil, and humanity not worthy of salvation, the final frames of the film do 
not stress the heroine's satisfaction with ultimate destruction, but instead stresses her deepest sorrow, which accompanies all of her last actions. It appears that the idea of the vanity of Christ's sacrifice still unsettles von Trier. Not surprisingly, he names the last cycle, the Depression Trilogy, possibly alluding to a spiritual state, associated with the loss of faith and disillusionment in Christianity.

\section{Список литературы}

Бьоркман С. Ларс фон Триер. Интервью / пер. со швед. Ю. Колесовой. СПб. : Азбука-классика, 2008. 352 с.

Долин А. Всюду - боль : Интервью с Л. фон Триером [Электронный ресурс]. 2009. URL: http://expert.ru/expert/2009/22/vsyudu_bol/ (дата обращения: 12.12.2014).

Долин А. Ларс фон Триер : Контрольные работы. 2-е изд., доп. М. : Новое литературное обозрение, 2015. $352 \mathrm{c}$.

Долин А. «Лежу в гробу...» : Интервью с Ларсом фон Триером [Электронный pecypc]. 2011. URL: http://www.gazeta.ru/culture/2011/06/29/a_3679141.shtml (дата обращения: 20.04.2014).

Долин А. «Нимфоманка»: послесловие [Электронный ресурc]. 2014. URL: http:// vozduh.afisha.ru/cinema/nimfomanka-posleslovie/ (дата обращения: 10.09.2014).

Достоевский Ф. М. Полное собрание сочинений : в 30 т. Т. 28, кн. 1 : Письма 1832-1859. Л. : Наука, 1985.

Касаткина Т. А. «Записки из подполья» в контексте черновых записей Достоевского 1864 года : Семинар для учителей в Старой Руссе : [аудиозапись] [Электронный pecypc]. URL: http://www.youtube.com/watch?v=t1CkcpgSqFo (дата обращения: 10.09.2014).

Сараскина Л. И. «Я дитя неверия и сомнения...» : Ф. М. Достоевский и символ веры в русской литературе XIX века // Ракурсы. Вып. 7. М. : ЛЕНАНД, [Государственный институт искусствознания], 2008. С. 330-355.

Торсен Н. Меланхолия гения. Ларс фон Триер. Жизнь, фильмы, фобии / пер. с дат. Я. Палеховой. М. : Рипол-классик, 2013. 704 с.

Badley L. Lars von Trier. University of Illinois Press, 2001. 216 p.

Lumholdt J. Lars von Trier : Interviews. University Press of Mississippi, 2003. 218 p.

Tiefenbach G. Drama und Regie. Lars von Triers Breaking the Waves, Dancer in the Dark, Dogville. Würzburg : Königshausen \& Neumann, 2010. 252 S.

\section{References}

B'orkman, S. (Yu. Kolesova, Transl.) (2008). Lars fon Trier. Interv'yu [Lars von Trier. Interview]. Saint Petersburg: Azbuka-klassika.

Badley, L. (2001). Lars von Trier. University of Illinois Press.

Dolin, A. (2009). Vsyudu - bol': Interv'yu s L. fon Trierom [Pain is Everywhere: Interview with L. von Trier]. Retrieved from: http://expert.ru/expert/2009/22/vsyudu_bol/.

Dolin, A. (2011). "Lezhu v grobu...»: Interv'yu s Larsom fon Trierom ["Lying in a Coffin...": Interview with Lars von Trier]. Retrieved from: http://www.gazeta.ru/ culture/2011/06/29/a 3679141.shtml.

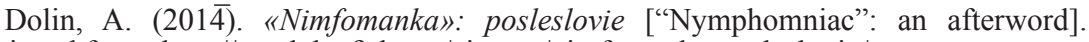
Retrieved from: http://vozduh.afisha.ru/cinema/nimfomanka-posleslovie/.

Dolin, A. (2015). Lars fon Trier: Kontrol'ny'e raboty'. [Lars von Trier. Tests]. ( $2^{\text {nd }}$ ed.). Moscow: Novoe literaturnoe obozrenie.

Dostoevskij, F. M. (1985). Polnoe sobranie sochinenij [Complete works]. (Vols. 1-30). (Vol. 28, book 1: Letters, 1832-1859). Leningrad: Nauka.

Kasatkina, T. A. "Zapiski iz podpol'ya»v kontekste chernovy'h zapisej Dostoevskogo 1864 goda: Seminar dlya uchitelej v Staroj Russe ["Notes from the Underground" in the context of Dostoevsky's drafts of 1864. Workshop for the Teachers in Stara Russa]. [Audio file]. Retrieved from: http://www.youtube.com/watch? $\mathrm{v}=\mathrm{t} 1 \mathrm{CkcpgSqFo}$.

Lumholdt, J. (2003). Lars von Trier: Interviews. University Press of Mississippi. 
Saraskina, L. I. (2008). «Ya ditya neveriya i somneniya...»: F. M. Dostoevskij i simvol very' v russkoj literature XIX veka ["I am a child of unbelief and doubt...": F. M. Dostoevs$\mathrm{ky}$ and the creed of faith in the Russian literature of the $19^{\text {th }}$ century]. Rakursy', 7, 330-355. Moscow: LENAND, Gosudarstvenny'j institut iskusstvoznaniya.

Tiefenbach, G. (2010). Drama und Regie. Lars von Triers Breaking the Waves, Dancer in the Dark, Dogville. Wurzburg : Konigshausen \& Neumann.

Torsen, N. (Ya. Palehova, Transl.). (2013). Melanholiya geniya. Lars fon Trier. Zhizn', fil'my', fobii [Melancholy of the genius. Lars von Trier. Life, films, and phobias]. Moscow: Ripol-klassik.

The article was submitted on 20.01.2015

Translated by Anna Dergacheva

Ольга Наумовна Турышева

доктор филологических наук, профессор кафедры зарубежной литературы, Уральский федеральный университет, Екатеринбург, Россия oltur3@yandex.ru
Olga Turysheva, Dr. Professor of the Cathedra of Foreign Literature, Ural Federal University, Yekaterinburg, Russia oltur3@yandex.ru 